\title{
Leadership Changes and Structural Reform After the 18th Party Congress in China
}

\author{
KJELD ERIK BRØDSGAARD AND NIS GRÜNBERG
}

\begin{abstract}
During the 18th Party Congress of the Chinese Communist Party in November 2012, and the 12th National People's Congress in March 2013, the Chinese leadership in Party organs and the state apparatus underwent a significant reshuffle. During this leadership change, virtually all leaders of the central organs were reappointed. While the actual structural and political reforms the new leadership is willing - and able-to make remain to be seen, an initial review of the top leadership in Party and state organs, including the ministries and provincial governments, reveals a relatively conservative team leading China in the coming five years. This article attempts to give a comprehensive review of the leadership changes, along with an initial analysis of the announced structural changes and the implications these changes could have for China's political recalibration and development.
\end{abstract}

Keywords: Chinese Communist Party, 18th Party Congress, 12th National People's Congress reform, leadership change

At the 18th Party Congress in November 2012, China initiated a leadership transition, which has now been completed with the election of a new government and a comprehensive reshuffling of provincial governors and Party secretaries. The result of last year's leadership transition in the Party was met with widespread disappointment as the new Standing Committee was composed of a majority of older and relatively conservative former provincial leaders, whereas younger and more reform-oriented candidates were passed over. The factional balance of the new Standing Committee was also heavily skewed towards former secretary general Jiang Zemin's faction. It is also difficult to claim that a generational change has taken place as the average age of the new top leadership is 63.4 years. The only two members below the age of 60 are the new secretary general, $\mathrm{Xi}$ Jinping, and the designated prime minister, Li Keqiang (Miller 2013; Brødsgaard 2012a; Li 2013; China Directory 2013). 
At the recent session of the National People's Congress (NPC), China completed its leadership transition by appointing a new government. A closer look at the composition of the new state leadership gives rise to a more optimistic view concerning the possibility of reform and the implementation of new, necessary policies. Thus, some of the leaders who were passed over in November last year have been able to stage a comeback. The most prominent example is former head of the central organizational department, Li Yuanchao, who did not make it to the Standing Committee at the 18th Party Congress, but managed to become vice president at the recent NPC meeting. Another example is the reform-oriented former provincial leader in Guangdong, Wang Yang, who also did not make it to the Standing Committee, but who was appointed vice premier at the NPC session, and therefore is in a good position to be promoted to the Standing Committee at the next Party congress in 2017.

\section{Personnel Changes at the Helm}

As expected, Secretary General Xi Jinping was elected president and Li Keqiang was elected prime minister. The new prime minister nominated a list of candidates for members of the State Council as vice premiers, state councilors and cabinet ministers. Vice premiers are ranked higher than state councilors, who are in turn ranked higher than cabinet ministers. The new vice premiers are Standing Committee member Zhang Gaoli, former state councilor Liu Yandong, former Guangdong provincial secretary Wang Yang, and former State Council secretary general and state councilor Ma Kai. The new state councilors are the new State Council secretary general Yang Jing, defence minister Chang Wanquan, former foreign minister Yang Jiechi, minister for public security Guo Shengkun, and former head of the State Assets Supervisory and Administration Commission (SASAC) Wang Yong. Liu Yandong is the only woman among these top state officials. The inner cabinet is joined by an additional 23 ministers - nine of whom are newly appointed. Among these, it is noteworthy that the former minister of land and resources, $\mathrm{Xu}$ Shaoshi, has been appointed head of the powerful National Development and Reform Commission, which is in charge of overall economic planning in China. It is also interesting that the former head of the China Investment Corporation (CIC), Lou Jiwei, has taken over the position as minister of finance and the former director of the Taiwan Office, Wang Yi, has been appointed foreign minister. 
However, since the previous foreign minister, Yang Jiechi, has been promoted to state councilor, he will be in charge of foreign policy work in the State Council, and formally be ranked above Wang Yi. Including Liu Yandong, there are three female ministers. In the previous government there were two ministers who were not members of the Chinese Communist Party (CCP). As the former minister of health Chen Zhu has resigned, the minister of science and technology, Wan Gang, is the only non-CCP member left. ${ }^{1}$

There are three members of the Standing Committee of the CCP who also hold top positions in the state apparatus. These are President $\mathrm{Xi}$ Jinping, Prime Minister Li Keqiang, and Vice Premier Zhang Gaoli. Politburo Standing Committee member Zhang Dejiang has been appointed chairman of the NPC and in this capacity is also involved in government work. It was rumoured that Standing Committee member Liu Yunshan, head of the Party secretariat and former minister of the powerful propaganda department, would become the new vice president. He is president of the Central Party School and since 1998 the head of this elite training centre has also held the position as vice president. But this arrangement has now been abandoned in order to bring $\mathrm{Li}$ Yuanchao into a top state post.

At the provincial level, considerable reshuffling has also taken place (see Table 1). It is noteworthy that $\mathrm{Hu}$ Chunhua has been appointed Party secretary in Guangdong. This is yet another indication that he is in line to become one of the key members of the so-called sixth generation, which will take over in 2023 when Xi Jinping and the fifth generation leave the scene. Another prominent member of the sixth generation is Sun Zhengcai, who has been appointed Party secretary of Chongqing. The only woman among China's provincial Party secretaries and governors is Sun Chunlan, who has been appointed Party secretary in Tianjin.

State-owned enterprises (SOEs) are also part of the power system in China (Brødsgaard 2012b; Eaton 2013). The 115 SASAC companies enjoy vice-ministerial status and a few of them ministerial status. ${ }^{2}$ This inclusion in the governance structure stems from the rank of their company leadership, the (Party) secretary, which in most cases also holds the post of the director (with the position of the secretary outranking the director in terms of power). The secretaries are appointed by Party organs; in the case of 53 of the central SOEs by the central CCP Organization Department. Their leaders are often rotated to take up positions in other companies or assume leading state and 
Kjeld Erik Brødsgaard and Nis Grünberg

TABLE 1: New Positions in the State Apparatus

\begin{tabular}{|c|c|c|c|}
\hline Position & Name & $\begin{array}{l}\text { CCP/PLA } \\
\text { positions }\end{array}$ & $\begin{array}{l}\text { Year } \\
\text { Born }\end{array}$ \\
\hline \multicolumn{4}{|l|}{ Central State } \\
\hline President & Xi Jinping & $\begin{array}{l}\text { Secretary General } \\
\mathrm{CCP} ; \mathrm{CMC}\end{array}$ & 1953 \\
\hline Vice President & Li Yuanchao & ССР РB & 1950 \\
\hline Premier & Li Keqiang & CCP SC & 1955 \\
\hline Vice Premier & Zhang Gaoli & CCP SC & 1946 \\
\hline Vice Premier & Ma Kai & ССР PB & 1946 \\
\hline Vice Premier & Liu Yandong $(\mathrm{F})$ & ССР PB & 1945 \\
\hline Vice Premier & Wang Yang & ССР РB & 1955 \\
\hline Secretary General SC & Yang Jing & $\mathrm{CC}$ & 1953 \\
\hline State Councilor & Chang Wanquan & CC; $\mathrm{CMC}$ & 1949 \\
\hline State Councilor & Yang Jiechi & $\mathrm{CC}$ & 1950 \\
\hline State Councilor & Guo Shengkun & $\mathrm{CC}$ & 1954 \\
\hline State Councilor & Wang Yong & $\mathrm{CC}$ & 1955 \\
\hline \multicolumn{4}{|l|}{ Ministries } \\
\hline Foreign Affairs & Wang Yi & $\mathrm{CC}$ & 1953 \\
\hline National Defense & Chang Wanquan & $\mathrm{CC}$ & 1949 \\
\hline NDRC & Xu Shaoshi & $\mathrm{CC}$ & 1951 \\
\hline Education & Yuan Guiren & $\mathrm{CC}$ & 1950 \\
\hline Science and Technology & Wan Gang & $\mathrm{CC}$ & 1952 \\
\hline State Security & Geng Huichang & $\mathrm{CC}$ & 1951 \\
\hline Supervision & Huang Shuxian & $\mathrm{CC}$ & 1954 \\
\hline Civil Affairs & Li Liguo & $\mathrm{CC}$ & 1953 \\
\hline Justice & Wu Aiying $(\mathrm{F})$ & $\mathrm{CC}$ & 1951 \\
\hline Auditor General & Liu Jiayi & $\mathrm{CC}$ & 1955 \\
\hline Finance & Lou Jiwei & CC; CIC secretary & 1950 \\
\hline HR and Social Security & Yin Weimin & $\mathrm{CC}$ & 1953 \\
\hline Land \& Resources & Jiang Daming & $\mathrm{CC}$ & 1953 \\
\hline Environmental Protection & Zhou Shengxian & $\mathrm{CC}$ & 1949 \\
\hline Governor of PBC & Zhou Xiaochuan & & 1948 \\
\hline $\begin{array}{l}\text { Housing and Rural-Urban } \\
\text { Development }\end{array}$ & Jiang Weixin & $\mathrm{CC}$ & 1949 \\
\hline Transport & Yang Chuantang & CC & 1954 \\
\hline Water Resources & Chen Lei & CC & 1954 \\
\hline $\begin{array}{l}\text { Industry \& Information Techno- } \\
\text { logy }\end{array}$ & Miao Wei & $\mathrm{CC}$ & 1955 \\
\hline Ethnic Affairs Comm. & Wang Zhengwei & $\mathrm{CC}$ & 1957 \\
\hline Public Security & Guo Shengkun & $\mathrm{CC}$ & 1954 \\
\hline Agriculture & Han Changfu & $\mathrm{CC}$ & 1954 \\
\hline Commerce & Gao Hucheng & CC & 1951 \\
\hline
\end{tabular}


TABLE 1: continued

\begin{tabular}{|l|l|l|c|}
\hline Culture & Cai Wu & CC & 1949 \\
\hline $\begin{array}{l}\text { National Health and Family } \\
\text { Planning Comm. }\end{array}$ & Lin Bin (F) & CC & 1954 \\
\hline SASAC & Wang Yi & CC & 1953 \\
\hline Local Government & Party Secretary & Governor/Mayor & \\
\hline Beijing (Municipality) & Guo Jinlong & Wang Anshun & $1947 / 57$ \\
\hline Shanghai (Municipality) & Han Zheng & Yang Xiong & $1954 / 53$ \\
\hline Tianjin (Municipality) & Sun Chunlan (F) & Huang Xingguo & $1950 / 54$ \\
\hline Chongqing (Municipality) & Sun Zhengcai & Huang Qifan & $1963 / 52$ \\
\hline Guangdong Province & Hu Chunhua & Zhu Xiaodan & $1963 / 53$ \\
\hline Fujian & You Quan & Su Shulin & $1954 / 62$ \\
\hline Zhejiang & Xia Baolong & Li Qiang & $1952 / 59$ \\
\hline Jiangsu & Luo Zhijun & Li Xueyong & $1951 / 50$ \\
\hline Shandong & Jiang Yikang & Guo Shuqing & $1953 / 56$ \\
\hline Henan & Guo Gengmao & Xie Fuzhan & $1950 / 54$ \\
\hline Hebei & Zhou Benshun & Zhang Qingwei & $1953 / 61$ \\
\hline Liaoning & Wang Min & Chen Zhenggao & $1950 / 52$ \\
\hline Jilin & Wang Ruilin & $\begin{array}{l}\text { Bayanqolu/Bayin- } \\
\text { chaolu }\end{array}$ & $1953 / 55$ \\
\hline Heilongjiang & Wang Xiankui & Lu Hao & $1952 / 67$ \\
\hline Inner Mongolia AR & Wang Jun & Bagatur/Bate'er & $1952 / 55$ \\
\hline Shanxi & Yan Chunqing & Li Xiaopeng & $1952 / 59$ \\
\hline Shaanxi & Zhao Zhengyong & Lou Qinjian & $1951 / 56$ \\
\hline Sichuan & Wang Dongming & Wei Hong & $1956 / 54$ \\
\hline Hubei & Li Hongzhong & Wang Guosheng & $1956 / 56$ \\
\hline Hunan & Xu Shousheng & Xu Shousheng & 1953 \\
\hline Jiangxi & Qiang Wei & Lu Xinshe & $1948 / 56$ \\
\hline Guangxi AR & Peng Qinghua & Ma Biao & $1957 / 54$ \\
\hline Yunnan & Qin Guangrong & Li Jiheng & $1950 / 57$ \\
\hline Qinghai & Luo Huining & Luo Huining & $1953 / 54$ \\
\hline Gansu & Wang Sanyun & Liu Weiping & $1952 / 53$ \\
\hline Tibet AR & Chen Quanguo & Losang Jamcan & $1955 / 57$ \\
\hline Xinjiang AR & Zhang Chunxian & Nur Bekri & $1953 / 61$ \\
\hline Ningxia AR & Wang Zhengwei & $1950 / 57$ \\
\hline Anhui & CCP Cianhua & Wang Xuejun & $1950 / 52$ \\
\hline & Zoss: & \\
\hline
\end{tabular}

Notes: PLA = People's Liberation Army; CCP = Chinese Communist Party; CIC = China Investment Corporation; $\mathrm{PBC}=$ People's Bank of China; SASAC $=$ State-Owned Asset Supervision and Administration Commission; $\mathrm{CC}=$ Central Committee; $\mathrm{CMC}=$ Central Military Commission; $\mathrm{PB}$

$=$ Politburo; $\mathrm{SC}=$ Politburo Standing Committee

Sources: www.gov.cn; www.baidu.cn; www.chinavitae.com. 
Party positions. Examples include former prime minister Li Peng's son, Li Xiaopeng, who in 2008 was transferred from his position as CEO of the big power company Huaneng to become executive vice governor in Shanxi. He was recently appointed governor of the province. Another example is Su Shulin, the former head of Sinopec, who in 2011 was transferred to become governor of Fujian province (Brødsgaard $2012 b$ ). The most recent move from big business to a state post is the transfer of the head of PetroChina, Jiang Jiemin, to become chairman of SASAC. ${ }^{3}$ This is a somewhat paradoxical appointment. SOE reform is a pressing issue in China, and in the process of reform, SASAC will play a key role. However, given his ties to the big oil companies, Jiang Jiemin will most likely be hesitant to spearhead initiatives that will limit the power of the SOEs.

The new leadership around Xi Jinping and Li Keqiang was expected to come up with a new political programme, refocus the political agenda and leadership style to address the many challenges China faces and define China's position in the international arena. Hopes were that these younger leaders would push political and structural reforms as well as the necessary economic rebalancing, and to end the 'lost decade' of reform-stop under their predecessors $\mathrm{Hu}$ Jintao and Wen Jiabao. ${ }^{4}$ As expected, they announced 'far-reaching' restructurings and reforms, and a 'streamlining of the government' in the form of structural changes at the ministerial level. In doing this, they followed the tradition of announcing some degree of reform, as all the new (first session) NPCs since 1993 have done. ${ }^{5}$ However, the structural reforms announced during this NPC were relatively conservative in nature and extent (and with one exception), the large central institutions (such as the National Development and Reform Commission (NDRC)) have kept or even bolstered their power.

\section{Limited Structural Change}

The largest change in this round of reforms is the dissolution of the Ministry of Railway (MOR). ${ }^{6}$ This had been expected for some time, especially after the Wenzhou train crash in July 2011 and the subsequent investigations that showed the enormous degree of corruption and abuse of authority in the ministry, leading to the arrest of its secretary (known as 'Mr 4\%') and the chief engineer on charges of large-scale corruption. The ministry had long been seen as a bloated and inefficient remnant from planned economy times, even having its 
own police and court system, employing almost 2 million people and investing as much as US\$ 120 billion in 2011.7 According to the reform plan, the ministry's policy planning and administrative functions will now be under the newly established State Railway Office, which itself is supervised by the Ministry of Transport. ${ }^{8}$ The commercial activities will be managed by a new SOE, the China Rail Transfer Corporation, which will most likely be a SASAC company with vice-ministerial rank. This move will boost efficiency and reduce embezzlement, but not change the monopoly of state-owned entities over the rail sector. However, this dissolution of a large and powerful ministry is also seen as a statement, to show that the leadership is willing and capable of acting against even strong vested interests at the ministerial level, if corruption and abuse of power are endangering regime legitimacy and socio-political stability.

The second reform will see the merger of the Ministry of Health and the National Population and Family Planning Commission, to form the new National Health and Family Planning Commission. This new commission will assume all functions except the macro and policy planning of a population strategy, which now lies within the NDRC. This restructuring suggests that rumours about a loosening of population control (the one-child policy) might be true, which makes sense in light of an ageing population. ${ }^{9}$ It will likely limit the authority of the population control bureaucracy (one of the most integrated ones, reaching down to every level of society), while boosting the leverage of the health sector administration.

The third reform is the merger of the State Food and Drug Administration and the State Commission on Food Safety, to form the new State Food and Drug Supervision Administration. Additionally, some specific authorities over food production and food sales are being absorbed from other ministries, to create a more comprehensive and unified administration, especially in the food sector. This clearly shows the leadership's awareness of the large problems the food and drug sectors face, struggling with huge quality and safety issues (Xue and Zhang 2013). While announced as a primary goal, it is unclear if and how this new organ will actually cut red tape and improve quality supervision, especially at local levels.

Fourth, the Administration of Press and Publication (APP) merges with the State Administration of Radio, Film and Television (SARFT). They will form the new State Administration of News, Broadcasting, Film and Television. This reform falls short of the hopes that both 
organs would be absorbed by the Ministry of Culture, rather than forming another large entity regulating the media sector. Together with the CCP propaganda department, the media sector now has three large, powerful organs in charge of supervision, administration and production. This relatively conservative outcome could be the result of the relatively weak Ministry of Culture, and the strong role of censorship and media control by the Party's propaganda department nested in SARFT and APP.

The fifth restructuring is seen as a logical step toward more comprehensive administration of maritime issues, with the creation of the State Oceanic Administration, which absorbs the China Marine Surveillance along with partial authorities from other ministries. These are authority over fishery policy formerly under the Ministry of Agriculture, the Antismuggling Office in the Customs Administration, and border patrols formerly under the Ministry of Public Security. Given the increasing attention on maritime issues, and China's strong and pronounced interests in the Yellow and South China Seas, this seems like a good move to target the fragmentation of maritime issues. Together with the Navy and the Maritime Security Small Leading Group headed by Xi Jinping, the new State Oceanic Administration will be an influential player in maritime issues, not least the Diaoyu/Senkaku conflict.

Restructuring number six is the shift of the functions of the regulatory body of electricity, the State Electricity Regulatory Commission (SERC), formerly a bureau-rank organ under the NDRC, which will be absorbed by the National Energy Administration (NEA). Although the NEA is also supervised by the NDRC, it has increased its leverage somewhat by incorporating the SERC, as well as through its new director, $\mathrm{Wu}$ Xinxiong, who holds full minister rank instead of vice-minister rank as the NEA's former director Liu Tienan did. ${ }^{10}$ This, however, falls short of the hopes and rumours of a planned 'energy super-ministry', ${ }^{11}$ that could assume comprehensive and strategic authority over energy planning, policy making and supervision. The energy sector remains one of the most valuable industries, and the energy SOEs as well as the NDRC are not interested in giving away their leverage over it, which would be required if a new energy ministry were to be established. In fact, the central energy SOEs have defended their monopolies, and the NDRC (together with the NEA) remain the most powerful authorities in energy planning and policy making (Downs 2008). The NDRC has also been able to get five full minister-rank officials in its leadership team, two more than before. 


\section{Implications of the Restructurings}

The restructuring measures outlined above have largely fallen short of the expectations many had for the new leadership, both in China and abroad. Except for the dismantling of the MOR, they constitute rather small changes, and their ability to reduce red tape and increase supervision effectiveness remains to be seen. It seems that powerful actors, especially in energy, natural resources, construction and the SOEs, have blocked deeper structural reforms that could have addressed inefficiency in state-owned industries and monopolies, thereby blocking any significant change in the supervision and administration of the most profitable sectors occupied by SOEs and the powerful central planning commissions. The downsizing from 27 to 25 ministry-level organs at the central level, again with the exception of the MOR, in fact has not created less powerful but rather more powerful central organs, and the effect on increasing efficiency and reducing bureaucracy is unclear. The NDRC, SOEs and other often-criticized planning institutions such as the Ministry of Land and Resources have remained untouched.

Similarly, there has been no significant political reform; in fact the CCP has bolstered its position in the driver's seat. Although, for example, the public security apparatus has no leader at the Standing Committee level as it had with Zhou Yongkang before, the domestic security apparatus remains better funded than the People's Liberation Army. This shows the continued preference of hard measures to ensure stability and control the populace, and to curb unrest and social protest movements. The Party has without doubt shown that it acknowledges the challenges of corruption, weak supervision, red tape and increasing inequality, ${ }^{12}$ but it is not ready to delegate authority to non-party organs or even civil society. Another explanation is the strong role of vested interests, which use the integration of political and commercial authorities to create and enlarge their wealth, while blocking change for a more transparent and better supervised arrangement that potentially could impede their ability to accumulate wealth. However, it must be noted that the first term of the NPC (five years) in China usually is the weaker one for the leadership, which first has to create its own alliances and establish a power base throughout the system. So, there might be more reforms after the 19th Party congress in 2017, where five new officials will enter the Standing Committee due to the mandatory retirement age: Zhang Dejiang, Yu Zhengsheng, Liu Yunshan, Wang Qishan and Zhang Gaoli. As discussed above, a number of the new leaders likely to enter the Politburo and 
Standing Committee in 2017 are more reform oriented than the relatively conservative, stability-focused line-up today. All in all, restructurings and reforms have only been pushed through in some political focus areas of the $\mathrm{Xi}-\mathrm{Li}$ administration, such as maritime issues, and in the most pressing social hot-button sectors, such as food security and the weak health sector. Industrial powerhouses and 'super ministries' at the central level have remained in the driver's seat, and the marriage of political and commercial power seems unchallenged.

\section{Political Programmes and Focus}

Xi Jinping has been surprisingly quick in coining his own political programme with the 'China Dream' and the 'rejuvenation of the Chinese nation', which include the main goals of 'prosperity and happiness' and 'revitalization' (at times translated 'rejuvenation') of the Chinese people. ${ }^{13}$ While it is CCP Secretary General Xi's job to create China's overarching programmatic course, Premier Li also has set his own goals by stating that he will make urbanization his priority area, including the goal to move 400 million people to cities and towns within the next decade. ${ }^{14}$ It is hoped that this urbanization will become a catch-all cure for some of China's most pressing issues. It is seen as a key to economic rebalancing toward more consumption-led growth, but also aims to keep some drive in investment projects while increasing social equity and lifting living standards of the population. While these slogans and goals seem quite similar to those of the Hu-Wen leadership, there are, however, some differences.

The 'China Dream' was already introduced as a programmatic slogan during the CCP congress in October last year and has been well-accepted by both official and popular media, responding to the increasing nationalistic and economic aspirations of the Chinese. There has also been criticism, and some refer to it as the 'China Dreams', in plural, suggesting that ordinary people have different dreams than the rich and powerful. However, the slogan has proven to be flexible and inclusive enough to become a political programme, while also including several key elements that are part of the 'rejuvenation of the Chinese nation'. This latter campaign has historic antecedents and pays respect to the former leaders' programmes, as well as the growing confidence and pride of the Chinese people. The important roles of 'happiness' and 'prosperity' in the programme can be understood as references to both Deng Xiaoping's 'well-off society' and the aim of sustaining economic 
growth, as well as addressing concerns of inequality. 'Happiness' continues $\mathrm{Hu}$ Jintao's 'harmonious society' notion, but also addresses the continued and increasing need for infrastructure, social services and issues of declining social satisfaction. The 'rejuvenation' is a strong reference to the 'century of humiliation' that started with the opium wars and lasted until the founding of the People's Republic of China, but for many in fact only ended with the economic growth of recent times. Growing nationalism and pride among the general population back this programme, and it has been a smart move to gather popular consent around the leadership by presenting it as both distinctively Chinese and popular rather than elitist. The People's Daily quotes $\mathrm{Xi}$ as saying that 'personal fate is intimately linked to the destiny of the nation', ${ }^{15}$ playing to the responsibilities of cadres, but also the nationalistic pride of the people. The recent state-sanctioned criticisms of Apple seem to be a clear manifestation of this programme, a new-found confidence, and not the programmatic 'biding our time and hiding one's strengths' from before. This is a bold move to create a new identity for the leadership, showing that China sees its rise as an international superpower, while domestically betting on nationalistic feelings and pointing away from legitimacy issues of the CCP. It is also a flexible political programme for cadres to develop their own tool box in the localities, to shift from the strongly stability- and control-focused policies of the Hu-Wen administration, toward a more outcome-oriented policy regime, as opposed to a purely output-oriented one.

At the same time, it shows a China that will test its limits more than before, while not addressing its own domestic ills, beyond the realm of political propaganda. The strong position of central planning commissions, SOEs and the CCP's continued supremacy over the legal sector remain unbroken. The increased headwind that foreign companies face in China, exemplified by the recent Apple case ${ }^{16}$ will most likely not cease any time soon. China is growing more confident toward the outside, while the internal power structures and social fault lines remain in place.

\section{Conclusion}

The Party Congress and the recent NPC have marked a significant turnover of cadres at the top levels of both the CCP and the state apparatus. With a majority of top-level Party and state offices under new leadership, the recent Party congress and NPC must certainly be re- 
garded as an important shift in the political setup in China. While the Politburo is staffed with relatively old and conservative cadres, in the combined leadership of party and state, the factions remain fairly balanced, although people associated with Jiang Zemin have maintained their influence. Many observers point to the many serious challenges to Party legitimacy, and to social and economic problems that have kept the government busy over the last few years, such as significant cases of corruption (the Bo Xilai affair), growing inequality and the increasing distrust of the population toward the leadership. The new team is seen as an experienced and influential 'maintenance $\mathrm{crew}^{\prime}$ ', which will be able to fix the worst problems and sustain a certain degree of growth and social stability. The many relatively young and reform-oriented officials in the second and third row, waiting for their turn in 2017 and 2022, certainly boost expectations for more substantial reforms, and especially political reform, after the next leadership transition beginning at the 19th Party congress in 2017.

The reforms at hand are certainly not enough to address some of the most pressing issues for the economy, and the state-owned sectors are still in a preferential position against private, and especially foreign companies. Nevertheless, China's economy is growing steadily and there are no indications that this will change in the next few years. The next leadership transition in five years might bring about more substantial reforms if China manages to overcome the rising tensions related to social issues, the challenges of economic rebalancing, and given that no unpredictable, serious, destabilizing events occur, such as war, internal turmoil or a new bird flu epidemic. A total transition to democracy or a free market economy seems unrealistic and naive in this light, and the world is probably best served with seeing China as the nation sees itself: an increasingly confident actor that, although facing huge domestic challenges, has a strong party-state eager to establish itself as one of the main powers in the international community.

Kjeld Erik Brødsgaard is professor at the Department of International Economics and Management and the director of the Asia Research Centre, Copenhagen Business School. Nis Grünberg is a PhD Fellow at the Asia Research Centre, Copenhagen Business School. 


\section{NOTES}

1 'Premier Li nominates new cabinet members' [online], Xinhua, 16 March 2013, available from: http://news.xinhuanet.com/english/china/2013-03/16/c_132238467. htm (accessed 11 May 2013); 'China's parliament endorses new cabinet lineup' [online], Xinhua, available from: http:// news.xinhuanet.com/english/china/201303/16/c_132238680.htm (accessed 11 May 2013).

2 At the time of writing there were 115, since August 2013 the official list issued by SASAC contains only 113 SOEs, showing the ongoing restructurings in the sector.

3 'CNPC President takes over at SASAC' [online], Caixin, 25 March 2013, available from: http://english.caixin.com/2013-03-25/100506110.html (accessed 13 May 2013).

4 'On Way Out, China's Leader Offers Praise for the Status Quo' [online], The New York Times, 8 November 2012, available from: http://www.nytimes. com/2012/11/09/world/asia/hu-jintao-exiting-communist-leader-cautions-china. html?pagewanted=all\&_r=0 (accessed 13 May 2013).

5 'China's Xi underscores economic growth, market-oriented reforms' [online], Xinhua, 12 December 2012, available from: http:/ / news.xinhuanet.com/english/china/201212/06/c_132024066.htm (accessed 12 May 2013); 'Chinese to streamline gov't by strengthening industry associations' [online], Xinhua, 2 April 2013, available from: http:/ / news.xinhuanet.com/english/china/2013-04/02/c_132279942.htm (accessed 13 May 2013); 'NPC and CPPCC 2013 Annual Sessions Homepage' [online], Xinhua, March 2013, available from: http:/ / www.xinhuanet.com/english/special/2013lh/ (accessed 13 May 2013); Gilley (2013).

6 'Graphic: Super Ministry' [online], Caixin, 11 March 2013, available from: http:/ / english.caixin.com/2013-03-11/100500108.html (accessed 13 May 2013).

7 'How Dangerous Liaisons Led to Massive Corruption' [online], Caixin, 14 August 2012, available from: http://english.caixin.com/2012-08-14/100424022.html (accessed 13 May 2013).

8 'Xingzheng tizhi gaige ruhe shenhua' (How institutional reform will be deepened), People's Daily, 11 March 2013, available from: http://politics.people.com. cn/n/2013/0311/c1001-20740990.html (accessed 13 May 2013).

9 See note 5 .

10 'China's cabinet announces official appointments' [online], Xinhua, 26 March 2013, available from: http:/ / english.peopledaily.com.cn/90785/8183695.html (accessed 13 May 2013).

11 'China Plans New Energy Super-Ministry' [online], China.org, 9 January 2012, available from: http://www.china.org.cn/business/2012-01/09/content_24361277.htm (accessed 12 May 2013).

12 'CPC Discipline Watchdog Vows to Crack Down on Corruption' [online], Xinhua, 20 November 2013, available from: http:/ / english.people.com.cn/90785/8025801. html (accessed 13 May 2013); 'New CPC Leadership Rejects Extravagance, Bureaucracy' [online], Xinhua, 4 December 2012, available from: http://news.xinhuanet. com/english/china/2012-12/04/c_124047353.htm (accessed 13 May 2013).

13 'Shixian Zhongguo Meng Xu Zou Zhongguo Ludao' (Realizing the Chinese Dream Requires Walking a Chinese Path) [online], People's Net, 28 March 2013, available from: http:/ / theory.people.com.cn/n/2013/0328/c83855-20942878.html (accessed 13 May 2013).

14 'Future Driver of Growth' [online], China Daily, 24 December 2012, available from: http://www.china.org.cn/opinion/2012-12/24/content_27495446.htm (accessed 13 May 2013).

15 'Jun Meng de Jiaoxiang' (The Symphony of a Strong Army) [online], People's Net, 28 
Kjeld Erik Brødsgaard and Nis Grünberg

March 2013, available from: http://www.people.com.cn/24hour/n/2013/0328/ c25408-20944081.html (accessed 13 May 2013).

16 'Apple in Discord in China' [online], The New York Times, 1 April 2013, available from: http:/ / dealbook.nytimes.com/2013/04/01/apple-of-discord-in-china/ (accessed 13 May 2013).

\section{REFERENCES}

Brødsgaard, Kjeld Erik 2012a. 'A Note on the 18th Party Congress of the CCP: Personnel Changes and Factional Alliances'. The Copenhagen Journal of Asian Studies 30(2): 61-73.

Brødsgaard, Kjeld Erik 2012b. 'Politics and Business Group Formation in China: The Party in Control'. The China Quarterly 211: 224-248.

China Directory 2013. Tokyo: Radiopress.

Downs, Erica 2008. 'China's "New" Energy Administration'. China Business Review November-December: 42-45.

Eaton, Sarah 2013. 'Political Economy of the Advancing State: The Case of China's Airlines Reform'. The China Journal 69: 64-86.

Gilley, Bruce 2013. 'Policy Reform Measures Highlight Potential for Transformation'. China Brief 13(7): 5-8.

Li, Cheng 2013. 'Rule of the Princelings'. The Cairo Review of Global Affairs, 10 February 2013, available from: http:/ / www.brookings.edu/research/articles/2013/02/chinaxi-jinping-li (accessed 12 February 2013).

Miller, Alice 2013. 'The New Party Politburo Leadership'. China Leadership Monitor 40, available from: https://www.hoover.org/publications/china-leadership-monitor/article/137951 (accessed 17 August 2013).

Xue, Jianhong and Wenjing Zhang 2013. 'Understanding China's food safety problem: An analysis of 2387 incidents of acute foodborne illness'. Food Control 30(1): 311-317. 